\title{
The IUFRO 1964/68 Inventory Provenance Trial of Norway Spruce in Nyírjes, Hungary - results and conclusions of five decades
}

\author{
Éva UJVÁRI-JÁRMAY \\ NARIC Forest Research Institute, Mátrafüred, Hungary \\ László NAGY \\ NARIC Forest Research Institute, Sárvár, Hungary

\section{Csaba Mátyás} \\ University of West Hungary, \\ 9401 Sopron, Pf. 132, Hungary, e-mail: cm@emk.nyme.hu \\ (corresponding author)
}

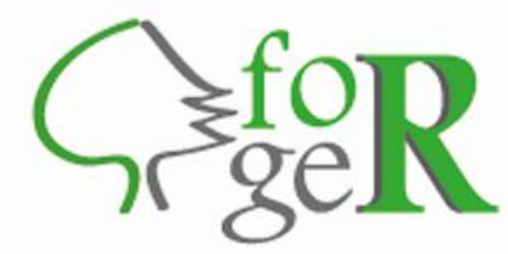

The publication of this documentary study has been supported by the project "Towards the Sustainable Management of Forest Genetic Resources" FORGER FP7- 289119, financed by the European Commission 


\section{About the authors}

Éva Ujvári-Jármay is retired research counselor at the Experiment Station of the NARIC Forest Research Institute (ERTI) in Mátrafüred, Hungary

László Nagy is senior research associate at the Headquarters of the NARIC Forest Research Institute (ERTI) in Sárvár, Hungary

Csaba Mátyás, corresponding author, is professor emeritus at the Institute of Environmental and Earth Sciences, Faculty of Forestry, University of West Hungary, Sopron, Hungary

\section{Citation of the paper}

Ujvári-Jármay, É. - L. Nagy - Cs. Mátyás:

The IUFRO 1964/68 inventory provenance trial of Norway spruce in Nyírjes, Hungary results and conclusions of five decades. Documentary study. Acta Silvatica \& Lignaria Hungarica, Vol. 12, Special Edition (2016) 178 p. DOI: 10.1515/aslh-2016-0001 